\title{
p.142 側定呯佂
}

体亩 学 咞 卶 $15-5$

\section{2. 高等学校碚莱課程における男子生徒の姿然についての研究 (その II )}

1. 目的, 方法

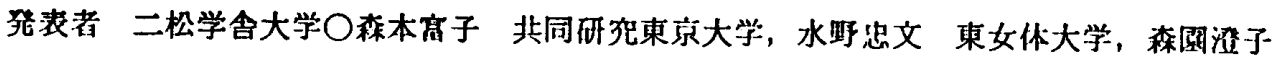

この研究は44年度高等学校職業課程（商業男子）生徒の资妿教育につついて多棣化衫雜化する社会のなかで男子生 徒の姿势教育の変谷についての基砤瓷料とし，併せてA商業高枚の特長的要素としての生徒8.9数の割合女生徒8.9対 男生徒1.1という变形のなかで行われている教育全体を含めた籍察㧍よび，立位侧面姿势についての Confomataur を

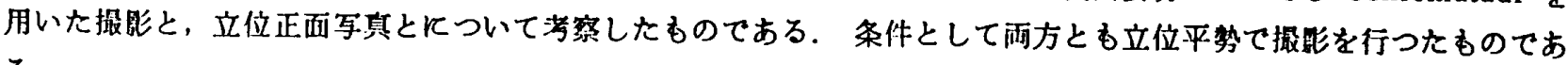
ð.

\section{II 桔 果}

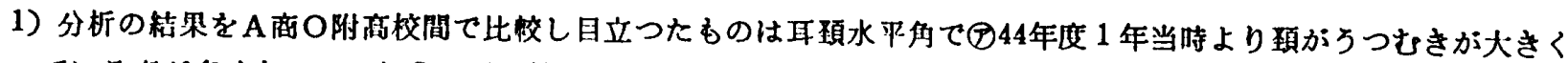

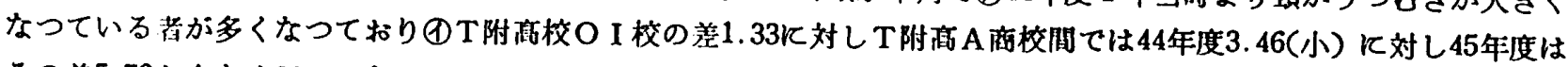

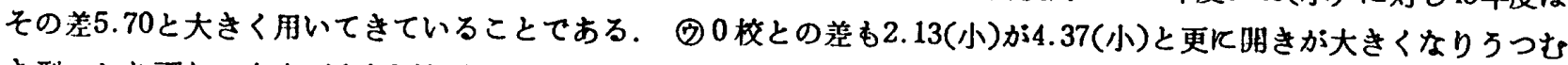

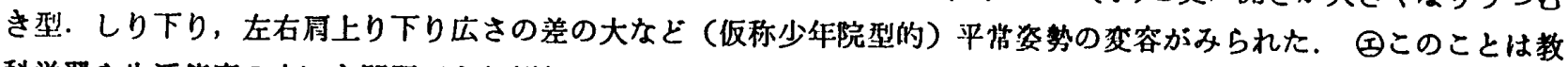

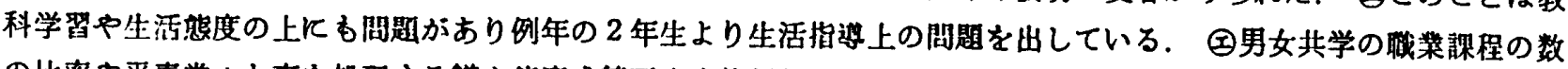

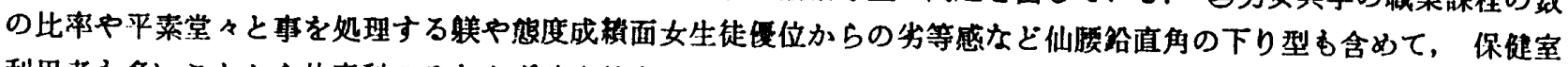
利用者も多いことから体育科のみならず改定教育㑊程で特に姿勢教育重視の要があるようである.

\section{3，高䙳学生の体格と体力の推移について}

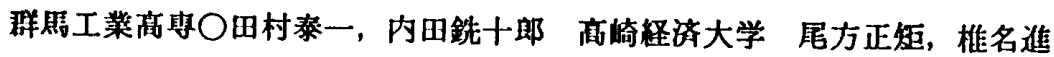

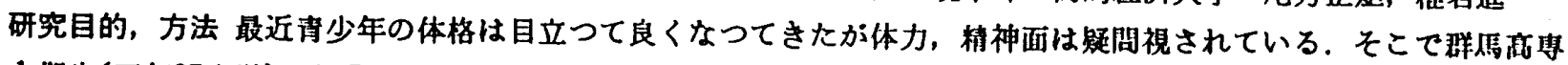
の 1 期生(昭年37入学)より 5 期生までの 1 年時〜 5 年時まで年時の形热, 体力泪定の数種目を抽山し，その推移を検討

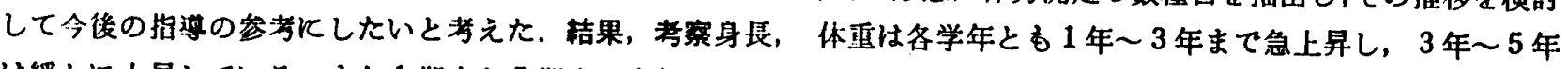

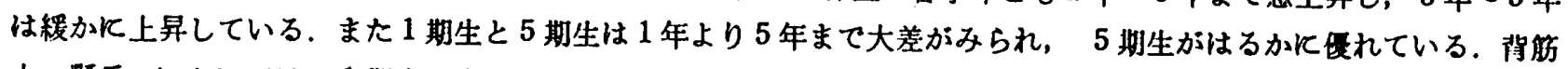

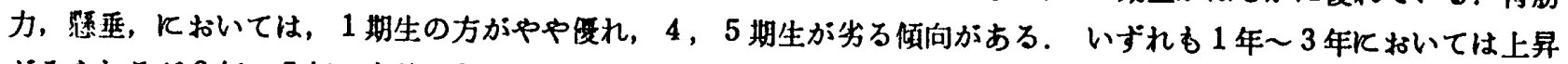
がみられるが 3 年〜 5 年は大差がない. 立巾跳は 1 年より入学順飞遂次高い值を示し平行線的に 5 年まで顺調に上昇

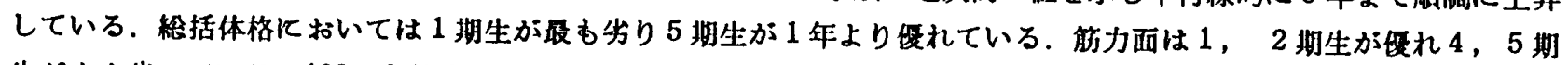

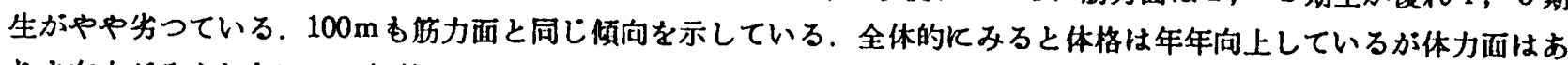

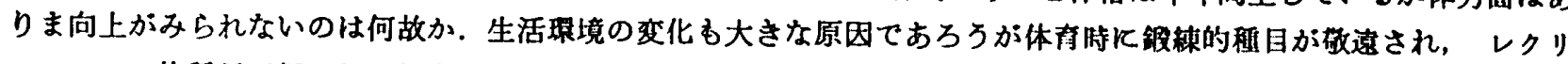

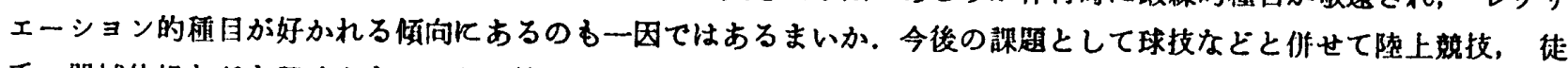

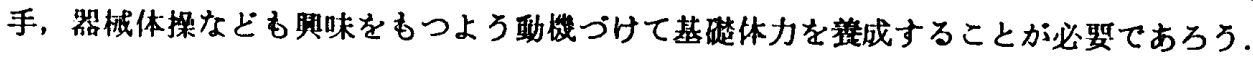

\section{Step Test におけるノモクラム作成のための基碐的研究}

Step exercise 九州大学○浦和子, 今野道勝, 勝田成 の实験を行つた。

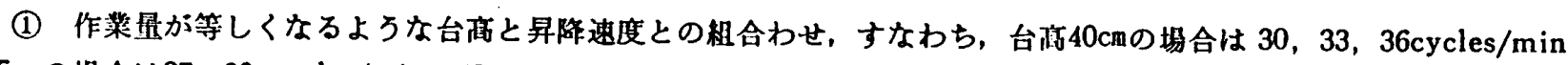
$45 \mathrm{~cm}$ の場合は27, $30 \mathrm{cycles} / \mathrm{min}, 50 \mathrm{~cm}$ の場合は, 24, 27, $30 \mathrm{cycles} / \mathrm{min}$ で, それぞれ 3 分間の作羓を行わせた.

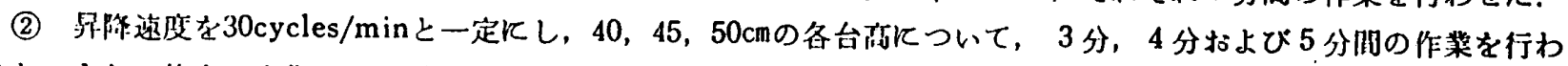

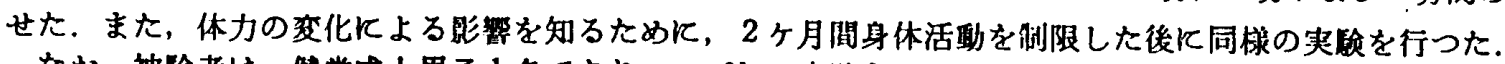

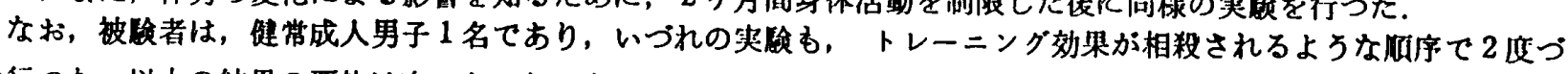
つ行つた．以上の絬朵の要䄪は次のとおりである。

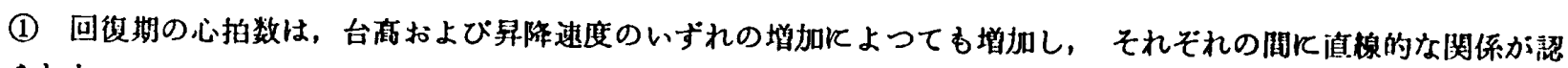
められた.

(2) 同一の作業強度で, 昇降速度の速い堨合ほど心拍数の回後が遅延する㑯向があり, 両者の凮には, 直線的な 関係が係認められた。

(3) 回㪀期の心拍数は，通動諓䊦洔間の增加火ともなつて增加する傾向が認められた。しかし・台离の違い下よ り、その関係は一定ではなく，両者の間にはかならずしも直線的な関係は認められなかつた。 